\title{
Rigosertib Sodium
}

National Cancer Institute

\section{Source}

National Cancer Institute. Rigosertib Sodium. NCI Thesaurus. Code C71355.

A synthetic benzyl styryl sulfone analogue with potential antineoplastic activity. Polo-like kinase 1 inhibitor ON 01910.Na inhibits polo-like kinase1 (Plk1), inducing selective G2/M arrest followed by apoptosis in a variety of tumor cells while causing reversible cell arrest at the G1 and G2 stage without apoptosis in normal cells. This agent may exhibit synerg istic antitumor activity in combination with other chemotherapeutic agents. Plk1, named after the polo gene of Drosophila melanogaster, is a serine/threonine protein kinase involved in regulating mitotic spindle function in a non-ATP competitive manner. 